\title{
SEMIWORDS AND AFFIXOIDS: THE TERRITORY BETWEEN WORD AND AFFIX*
}

\author{
ISTVÁN KENESEI \\ Research Institute for Linguistics, Budapest, and University of Szeged \\ Benczúr u. 33, Budapest, H-1068, and Egyetem u. 2, Szeged, H-6722 \\ Hungary \\ kenesei@nytud.hu
}

\begin{abstract}
This paper is concerned with the status of bound forms in compounds and other lexical items, but it ultimately aims at setting up a hierarchy of lexical items of various degrees of "freedom", making use of clear-cut criteria applicable in at least one (fairly large) group of languages. In spite of the difficulties of the various (phonological, morphological, lexical, and semantic) definitions of 'word', Bloomfield's characterization of minimum free forms is applied to designate items at the top of the hierarchy, which are called 'autonomous words'. Bound forms that allow autonomous words to occur between them and the lexical item they are bound to are 'dependent words'. The novelty of this paper lies in dividing the rest of the lexical items "below", i.e., 'nonwords', into three groups: semiwords, affixoids, and affixes, based on a new application of a familiar operation, coordination reduction, which is shown to work both backward and forward for some items, but only backward reduction is possible for others.
\end{abstract}

Keywords: free/bound form, coordination reduction, backward/forward deletion, compounding, binary/n-ary coordination

* Special thanks are due for data (and/or discussions) to Marcel den Dikken, Gisbert Fanselow, Franck Floricic, Alex Grosu, Jutta Hartmann, Anikó Lipták, Lanko Marušič, Izaskun Perez Gonzales, Giampaolo Salvi, Sergio Scalise, Peter Sherwood, Mohinish Shukla, and Daniel Wedgwood - even though not all their data have been made use of here. I am grateful to Geert Booij and an anonymous referee for their comments on an earlier version, as well as audiences at the 12th International Morphology Meeting, May 2006, Budapest, and the Research Institute for Linguistics, Budapest. Needless to say, they carry no responsibility for the analyses and proposals. 


\section{Introduction and overview}

Morphology is an interesting field of inquiry in current linguistics probably because we still do not know whether it exists. While few deny the necessity of a list of items whose forms and/or meanings are unpredictable, i.e., the lexicon, or the necessity of a system of principles, rules, conditions, or templates that determine how items from the lexicon can be put together, i.e., syntax, the last word has not been said about whether morphology is necessary as an independent component of grammar. Even if the territory of what has been regarded as morphology is carved up between the three 'safe' chapters of lexicon, phonology, and syntax, the problems it has addressed will remain with us.

One such issue is whether or not there is a continuum between (derivational) affixes and words, i.e., constituents of compounds. Since there is a large area of overlap between derivation and compounding, as evidenced by various properties from headedness to bracketing paradoxes, at least in principle it is possible to assume that the two are but different sides of the same coin. It is then a question of some importance whether a given item proves to be an affix or a constituent of a compound, i.e., a 'word'. But even if everyone agrees in attributing both derivation and compounding an entirely different status, the question of whether the area between them is articulated or not remains to be answered. If there is a 'slide' leading from word to affix, it is pointless to try to draw sharp dividing lines. If, however, we claimed that it is not a slide but a 'stepladder' that connects these two extremes, the onus of proof would lie on us to show that the land between them is clearly marked out. This will be our primary purpose in the present paper.

We will invoke well-defined grammatical processes that any native speaker can (and presumably does) rely on to distinguish and classify lexical items of various degrees of combinability and/or independence. It will also be shown that these processes have a clear rationale, which accounts for why they operate on distinct morphological or lexical objects. In addition to the tests for wordhood based on internal stability and positional mobility (cf., e.g., Lyons 1968) as well as those based on coordination reduction well-known from the literature (cf. Höhle 1982; Toman 1985; Booij 1985), we will make use of the properties of forward and backward deletion as described by Wilder (1997) to argue for the difference between the items involved in the various processes. 
We will proceed by first recapitulating the literature on the definition of word. Next we will chart the territory below the level of the word, drawing first on the familiar test of coordination reduction and examining what type of constituents (i.e., prosodic, lexical or other) take part in the process. Coordination reduction is found to work both forward and backward in some cases, while in others only backward reduction is possible. Finally, coordination reduction is examined in the context of the two main types of coordination: binary and $n$-ary coordination.

\section{Words}

\subsection{The domain of relevance}

If faced with the task of determining what the word is, first of all it has to be noted that the notion of 'word' makes sense only in the conceptual territory that lies between two (largely ideal) extremes in the languages of the world, which we may call the 'non-word-based languages'. At one end we find languages whose words are each coextensive with one invariable morpheme, cf., e.g., Lyons (1968) or Comrie (1981). They are traditionally called isolating or (fully) analytic languages, and examples are customarily cited from Chinese or Vietnamese.

(1) wo men tan tcin le

(Chinese; McManis et al. 1991, 157)

I plur play piano past

'We played the piano.'

At the other end are languages which combine a large number of morphemes into a single unit often corresponding to a whole sentence, so it may be stated that their sentences are coextensive with words, cf. Comrie (1981). These polysynthetic languages are found, for example, in the Inuit and the Munda language families.

(2) po- pon- kon- t- am

stab belly knife non-past thee

(Sora, Munda; McManis et al. 1991, 160)

'(Someone) will stab you with a knife in (your) belly'

It is, however, far from easy to define what counts as a word even in the territory between these extremes. If one is not committed to the somewhat radical view that "words are perceived rather than formed" (Julien 2002, 36; emphasis in the original), it seems worthwhile to examine this question. Generally, such definitions depend on language-specific tests 
that serve as indicators of the intuitive choices native speakers of the language in question make. This may underlie observations often made in theoretical or practical treatises of the notion such as the following ones: "Not only are there considerable difficulties in pinning down any universally applicable notion of 'word', it appears that even when we restrict ourselves to morphological criteria within a single language we find that the term itself covers a multitude of sins, which need to be carefully distinguished" (Spencer 1991, 45); "the conception 'word' is determined afresh within the system of every language, and as a result the word-as-element-of-speech is language-specific, not language universal." (McArthur 1996, 1025)

\subsection{Words defined: autonomous and dependent words}

The definition almost universally quoted is Bloomfield's: "Forms which occur as sentences are free forms. [...] A word, then, is a free form which does not consist entirely of (two or more) lesser free forms; in brief, a word is a minimum free form" (1933, 178; emphasis in the original). But he also makes reference to a property of uninterruptability that the form blackbird has in contrast with the "two-word phrase" black bird. Lyons (1968, 202-3) takes this property, which he calls 'internal stability', to be the defining function of wordhood together with positional mobility, thus introducing the notion of 'grammatical cohesion'. Ultimately these features are used to determine what has come to be called the 'morphological or grammatical word' as against the orthographic, phonological, semantic, lexical, etc., notions of word, cf., e.g., McArthur (1996).

We may distinguish between two subtypes of word along the lines laid down by Bloomfield and Lyons. Bloomfield's minimum free forms that satisfy Lyons' criteria of grammatical cohesion constitute one such subclass, which we will call 'autonomous words'.

The other subtype comprises all bound forms that satisfy the same criteria of wordhood. Thus a bound form that can be separated from another (bound or free) form by an autonomous word is also a word, henceforth called 'dependent word', e.g., articles, prepositions, postpositions, (movable) pre- or postverbal particles, conjunctions, various clitics. ${ }^{1}$ The article or the preposition in bold type in (3) and (4), respectively, prove

${ }^{1}$ From the syntactician's viewpoint, these dependent words are mostly heads of (often functional) categories that take obligatory complements. Unlike the rest 
to be (dependent) words because the italicized autonomous words can be inserted between either of them and the forms preceding or following them.

(3) (a) behind the duckling

(b) behind or above the happy duckling

(4) (a) standing at the doors

(b) standing regularly at all the doors

If only bound forms can be inserted at the borderline of two forms, no word status is assigned to the bound form. In (5) the bound form -ation can be separated from the autonomous word compute only by other bound forms in italics in (5b). Therefore, -ation is neither an autonomous word, nor a dependent one.

(5) (a) compute-ation

(b) compute-er-ize-ation

Apparent counterexamples could arise if we were to regard derived forms of compounds as containing occurrences of autonomous words inside other words, cf. the examples below.

(6) (a) un-worthy

(b) un-trust-worthy

(7) (a) un-conscious

(b) un-self-conscious

But it becomes immediately clear that the italicized forms do not function as autonomous words, since they are opaque, for example, with respect to modification, cf. (8a), which shows that they are incapable of behaving the way autonomous words do: they cannot be combined with other autonomous words, as is the case in $(8 \mathrm{~b}-\mathrm{c})$.

(8) (a) un-(*some/full)-trust-worthy

(b) Kate has (some/full) trust in Jane.

(c) behind or right above the quite happy duckling

of the items in this list, clitics are not a grammatical category but a cover term. For an overview and classification, see, e.g., Halpern (1998). 
Lyons $(1968,204)$ notes that this feature of 'interruptability' accompanied by a lack of 'positional mobility' comparable to that of our autonomous words defines our dependent word as "not so 'fully' a word as other elements to which all the relevant criteria apply".

\subsection{Bound forms below the level of words}

The bound forms that are found below the level of (autonomous and dependent) words thus defined do not constitute a unified class. Various practitioners of the field have called attention to a distinction between 'genuine' affixes and 'misfits'. Marchand $(1969,356)$ differentiates suffixes, such as -able, -dom, -less from what he calls 'semi-suffixes', e.g., -like, -worthy, -monger, saying they are "midway between full words and suffixes. Some of them are used only as second-words of compounds, though their word character is still clearly recognizable". While Marchand's distinctions are clearly intuition-based, Höhle (1982) provides a test for differentiating affixes that behave like parts of compounds from affixes that do not. This is the well-known phenomenon of 'coordination reduction', abbreviated henceforth as CR. Höhle also noted that some vowel-initial suffixes syllabify with the preceding stems, while others form their own syllable. CR, then, was analyzed extensively from the vantage point of prosodic phonology by Booij (1985). Höhle and Booij found that certain words containing derivational affixes can undergo CR the same way as compounds can. Höhle's examples are cited under (9)-(11), where, as throughout below, we have added hyphens to mark constituents.

(9) (a) Karl liebt Herbst- und (Heinz liebt) Frühlings-blumen.

Karl likes autumn and (Heinz likes) spring flowers

(b) Karl verkaufte Herren-Mäntel und -Schuhe.

Karl bought men('s)-coats and shoes

(10) (a) hilf- und hoffnungs-los 'help- and hope-less'

(b) erkenn- und begreifs-bar 'recognize- and understand-able'

(c) Freund- oder Feind-schaft 'friend- or enemy-hood; friendship or enmity'

(d) Haupt- oder Neben-eingang 'main or side entrance'

(e) Ur- oder Spät-form 'early or later form' 


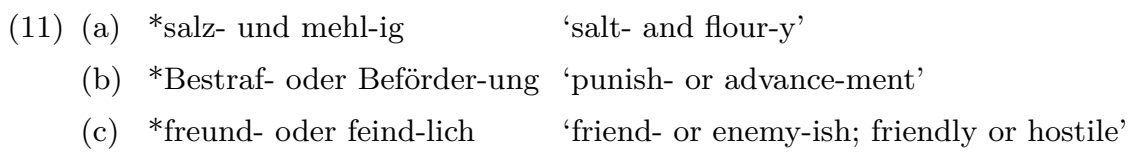

The compounds in (9) undergo CR: (9a) shows CR working 'from right to left', as it were, while (9b) illustrates the reverse direction. The suffixes and prefixes in (10) can undergo CR, while those in (11) cannot. Höhle also discusses the role of the connective element (Fugenelement) between the two parts (illustrated by the $s$ in (10a)) and phonological processes, such as the devoicing of the final obstruent of initial constituents in compounds, and suggests that the difference between the two classes of affixes can be captured by relying on 'strong' and 'weak' boundary markers, which Höhle attributes to Kiparsky (1975), and which is an idea first applied in morphological analysis by Siegel (1974/1979) as Class I and Class II affixes.

Toman (1985) follows Höhle (1982) in making use of the two boundaries, arguing that the strong boundary marks word status, and claiming that "both target and remnant of deletion must have word status" (Toman 1985, 429). Toman supports a deletion analysis of CR based on examples from compounds in non-symmetric syntactic constructions, cf.:

(12) weil sie die Wiederaufnahme der Inlands- und

because they the resuming of-the internal and

des grössten Teils der Auslands-flüge angekündigt haben

of-the larger part of-the foreign-flights announced have

'because they have announced re-opening of the internal flights and of the larger part of foreign flights'

Moreover, Toman complements Höhle's list in (10) by adding an example of coordinating two suffix-like items.

(13) eisen-artige oder -haltige Materialen

iron-like or containing materials

For quite some time the two classes of affixes had no individual names. Marchand's 'semi-suffix' did not catch on. Fabb (1998), in turn, called the non-independent constituents of compounds 'bound words'. To complicate matters further, the use of the new term 'affixoid' to signify the affixes undergoing $\mathrm{CR}$ was confined to German linguistics. Indeed, it may even seem pointless to try to find an appropriate term, since in recent 
times the whole issue of the classification of affixes has been called into question. Towards the end of his well-researched overview of neoclassical compounds and affixoids, Hacken $(2000,356)$ comes to the conclusion that "the idea of introducing one or more intermediate classes between derivation and compounding seems to be restricted to an episode in German linguistics of the 1970s and 1980s". ${ }^{2}$ His view is comparable to Booij's, who argues that "there is no sharp boundary between compounding and derivation" $(2005,6)$. He notes that the terms 'affixoid' and 'semi-affix' have been used to refer to morphemes that behave like parts of compounds and also have uses as independent lexemes, but their meanings are specific and more restricted when used in compounds. Following Höhle (1982), Booij makes a distinction between affixoids and 'non-cohering affixes', which behave as prosodic words, since they carry secondary stress, such as German -schaft '-ship' and Dutch -baar '-able', and -heid '-ity'.

Let us now sum up the relevant data, before we review and evaluate the various proposals in the literature. CR is fully applicable in the case of compounds, i.e., constructions of two word-sized lexical items, as in (14a). However, CR is also possible in the case of a number of other lexical items that are traditionally classified as affixes, while it is not possible when other affixes are involved, cf. (14b-e).

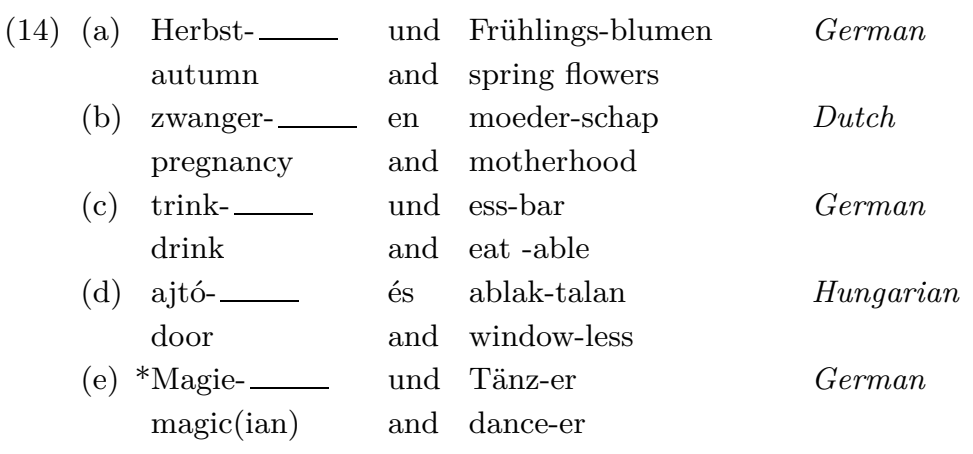

CR also applies to constructions whose initial or final constituents (Erstoder Zweitglieder) are not considered to be affixes but parts of com-

${ }^{2}$ We note here that although some of the findings below are relevant to the problems of neoclassical compounds, studied among others, by Artstein (2002), we will steer clear of them for most of the discussion. 
pounds, even though they never occur as either autonomous or dependent words, e.g.: ${ }^{3}$

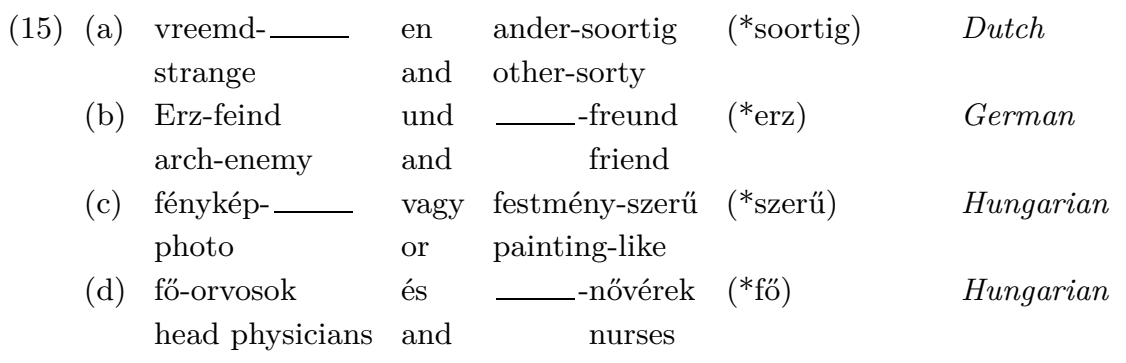

\section{Analyses and classifications}

\subsection{The domain of $\mathbf{C R}$}

The problem that a fundamentally syntactic operation poses by reaching into word-internal structure has intrigued a number of linguists, as has been seen above. Toman (1985) suggests that both the target and the remnant of deletion should be accorded word status. The clear advantages of this move are offset by the fact that most of the items in question never occur in the positions in which genuine words do, and even if they do, they do not have the same meanings, as Booij's (2005) contrast of boer 'farmer' and sigaren-boer 'cigar-seller' shows.

Booij (1985) argues that the minimal unit undergoing deletion in Dutch and German is the Phonological Word (PW). Artstein (2002) disagrees since on the basis of the examples in (16) he concludes that the minimal unit that undergoes deletion, i.e., the relevant prosodic constituent, at least in English, must be the Foot, rather than the PW.

(16) (a) *physio and psychologies $\leftarrow$ (physi)-(ólogy) and (psy)-(chólogy)

(b) physio and psychological $\leftarrow$ (physio)-(lógical) and (psycho)-(lógical)

Booij (2005) accommodates CR phenomena into three schemes of Constructional Morphology listed in (17), according to which the items illustrated in (15) fit the scheme in (17a) below, where the variables $x$ and $y$ stand for phonological strings and the variables $X$ and $Y$ for lexical categories.

\footnotetext{
${ }^{3}$ Only transparent forms undergo the process, cf. *black- and other songbirds, *black- and floorboards.
} 
(17) (a) compounding: $\left.\left.\left[[\mathrm{x}]_{\mathrm{X}}\right]_{[\mathrm{y}}\right]_{\mathrm{Y}}\right]_{\mathrm{Y}}$

(b) suffixation: $\left[[\mathrm{x}]_{\mathrm{X}} \mathrm{y}\right]_{\mathrm{Y}}$

(c) prefixation: $\left[\mathrm{x}[\mathrm{y}]_{\mathrm{Y}}\right]_{\mathrm{Y}}$

Booij groups his 'non-cohering' affixes, cf. (14b, c), together with constituents of compounds, thus assigning them to the pattern of (17a).

The first question we will address here is whether we can generalize from the findings in other languages to any universal minimal item that undergoes CR in a language. When data from Hungarian is examined, it appears that neither the PW, nor the Foot is adequate as the instrument of analysis. As is well-known from work by Vogel (1989), the PW is coextensive in Hungarian with the domain of vowel harmony (realized, among others, in the choice between affixes containing front or back vowels). Since the privative suffixes illustrated below belong to the class of harmonizing endings and therefore they form a single PW with their bases, they should not undergo CR, but they do, at least in certain dialects of the language.

(18) (a) ajtó-__ és ablak-talan

door and window-less

(b) erkély-__ és kémény-telen

balcony and chimney-less

Next, Hungarian has word-initial stress, and no (secondary) stress on affixes undergoing CR. Therefore, suffixes do not form separate feet, but even monosyllabic suffixes can undergo $\mathrm{CR}$, cf.:

(19) (a) feleség-___ és anya-ként

wife and mother-as

(b) hat-_ vagy nyolc-szor

six or eight times

Finally, affixes differ from constituents in compounds in assimilation properties. Assimilation is possible across boundaries separating suffixes from their bases, but not across boundaries separating constituents of compounds. In (20) the assimilation of the stop [ $\mathrm{t}]$ and the fricative $[\mathrm{s}]$ is examined, while in $(21)$ that of the affricate $\left[\mathrm{t}^{\mathrm{s}}\right]$ and the fricative $[\mathrm{s}]$. The (a) examples present affixes, those in (b) show compounds constructed 
of autonomous words, and the (c) examples contain bound forms, which were referred to as 'affixoids' or 'non-coherent affixes' above. ${ }^{4}$

(20) (a) hét- szer [he: $t^{\mathrm{s}} \mathrm{t}^{\mathrm{s}}$ er] seven times

(b) hét-számjegyes $[\mathrm{ts}] / *\left[\mathrm{t}^{\mathrm{s}} \mathrm{t}^{\mathrm{s}}\right]$ seven-figured

(c) hét-szerü [he:tserü: $]-*\left[\mathrm{t}^{\mathrm{s}} \mathrm{t}^{\mathrm{s}}\right]$ seven-like

(21) (a) nyolc-szor [ñolt ${ }^{\mathrm{s}}$ or] eight times

(b) nyolc-számjegyes $\left[\mathrm{t}^{\mathrm{s}} \mathrm{s}\right] / *\left[\mathrm{t}^{\mathrm{s}}\left(\mathrm{t}^{\mathrm{s}}\right)\right]$ eight-figured

(c) nyolc-szerü [ñolt ${ }^{\mathrm{s}}$ serü: $]-*\left[\tilde{n}_{\text {olt }} \mathrm{s}\left(\mathrm{t}^{\mathrm{s}}\right)\right.$ erü: $]$ eight-like

Under identical conditions of speed and level of formality, the initial obstruent of the affix, unlike the initial obstruent of the final constituent of the compound, can fully assimilate to the final obstruent of the base or the preceding constituent of the compound, cf. Kenesei et al. (1998, 436ff). Similar effects and distinctions are reported from German and Dutch in the literature reviewed above.

Since the (b) and (c) examples behave alike, the autonomous word számjegy(es) 'figure(d)' and the bound form -szerü 'like' belong to the same class with respect to assimilation. Since assimilation operates within the boundaries of the PW, but not across PWs, -számjegyes and -szerü prove to be PWs. Since the suffix -szer 'times' is subject to vowel harmony as well as to assimilation processes, it cannot be an independent PW, and since it carries no stress, it has no Foot status either. But, at the same time, -szer takes part in CR, and since both items that qualify as PWs and items that are not PWs undergo CR, CR cannot be based on prosodic constituents.

If no prosodic constituent coincides across languages with the class of lexical units that undergo the process of $\mathrm{CR}$, we have to resort to

${ }^{4}$ My thanks are due to Péter Siptár for elucidations on the exact processes, which are somewhat simplified for the sake of the presentation here. Note that similar distinctions have been commonplace in the literature since Nespor-Vogel (1986) or Mohanan (1986), among other works. 
marking these items each in its turn for the property in question. We will venture to establish a rationale for this move below.

\subsection{Extending CR}

CR can operate in two possible "directions". On the one hand, it can retain a constituent in the second conjunct and delete an identical constituent in the first conjunct, as in (22), a case of Backward Coordination Reduction (BCR). On the other hand, it can retain a constituent in the first conjunct and delete an identical one in the second conjunct, as in (23), called Forward Coordination Reduction (FCR). ${ }^{5}$

(22) (a) bookand newspaper-stands

BCR

(b) super-__ and supra-national

(c) gossip-_ or scandal-mongers

(23) (a) book-binders and -sellers

FCR

(b) anti-federalist and -nationalist (opinions)

(c) step-mothers and -fathers

Compounds formed of autonomous words undergo CR in both directions, as was seen in the German examples in (9a-b). Although some bound forms are capable of $\mathrm{CR}$ in both directions, some do not undergo the process at all, and others do so only in one direction. ${ }^{6}$

(24) (a) Erz-_ und Ur- feind

arch and ancient enemy

(b) Erz-feind und _ - freund arch enemy and (arch) friend

${ }^{5}$ Note the distinction between (22) and compounds like [[fish and vegetable] plate], [[book and magazine] rack], in which no CR takes place. Examples, but not the analysis, come from Di Sciullo-Williams (1987).

${ }^{6}$ Examples like (23c) can be interpreted also, and often more naturally, as 'fathers and stepmothers', since the second conjunct in (23c) makes perfect sense without the omitted first constituent. But what is at stake here is whether the intended interpretation, and consequently, CR, is possible at all. 
(25) (a) eisen-__ oder holz -haltige (Materialen)

iron or wood containing materials

(b) eisen-artige oder _ -haltige (Materialen) iron-like or containing materials

In (24) the first constituents are bound forms (as marked by the italics) and the second constituents are autonomous words. The bound forms can be coordinated and CR works both ways. In (25) the first constituents are autonomous words, and the second constituents are bound forms. Again the bound forms can be coordinated and CR operates in both directions.

In the following examples the bound forms do not have the same freedom.

(26) (a) un-__ oder blitz-sauber

un or bright clean

(b) blitz-_ oder un-sauber

In (26) the free form sauber can induce BCR and the two bound forms can be coordinated. But in (27) the bound form un does not allow FCR, unlike the bound form in (24b)

$\begin{array}{cc}(27) * u n \text {-sauber und } & \text {-elegant } \\ \text { unclean and } & \text { elegant }\end{array}$

The examples in (28) show (bases of) autonomous words as first constituents and bound forms as second constituents. Unlike the case in (25), neither BCR, nor FCR, that is, no coordination of bound forms is possible.

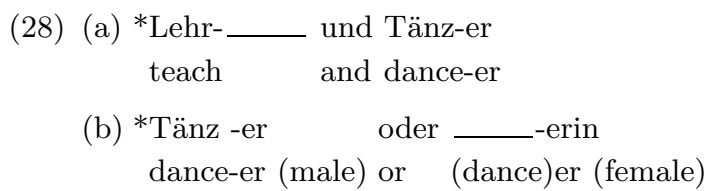

Hungarian provides us with a similar arrangement of data. (29) illustrates compounds containing autonomous words and CR works both ways.

(29) (a) telefon-___ és autó-javítás

phone and car-repair

(b) telefon-eladás és _-javítás

phone sale and repair 
In (30) the second constituents are bound forms: they allow CR in both directions.

(30) (a) telefon-___ vagy autó- szerű (dolgok)

phone or car- like things

(b) telefon-féle vagy ___-szerü (dolgok)

phone-kind or like things

'things like or resembling telephones'

In (31) the second constituents are bound forms again, but they do not allow $\mathrm{CR}$ in both directions. In fact, one of them, -ként allows BCR, but the other one, $-i g$ permits neither. ${ }^{7}$

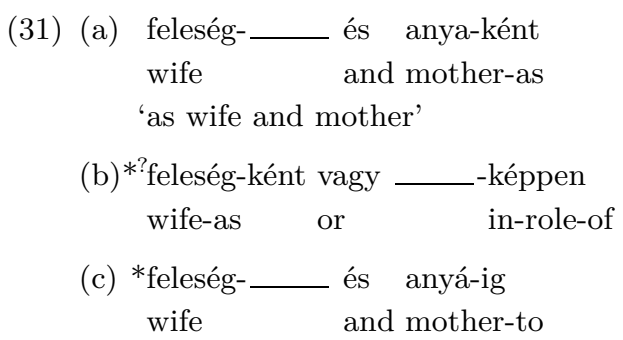

We may now draw an interim conclusion as to the classes of lexical items that take part in word formation processes. At least three further groups can be differentiated below the level of (autonomous or dependent) words, i.e., in the domain of bound forms, on the basis of whether or not CR is applicable, and if applicable, in which direction(s).

The class of words includes both autonomous and dependent words, with both subclasses occurring (relatively) freely with other autonomous or dependent words, as marked by the property of 'combinability' in Table 1 below, a reflection of Lyons' (1968) 'positional mobility' discussed in 2.2. The notion of semiword encompasses initial and final constituents of compounds that cannot occur outside the domain of compounds, i.e., they are not freely combinable with words or phrases into syntactic constituents, but can undergo $\mathrm{CR}$ in both directions. Affixoids correspond to affixes that take part in one type of CR: Backward Coordination Reduction. And finally, affixes are characterized by allowing no CR in either direction. Note that the traditional distinction of 'free and bound forms' is inapplicable to this classification, since its 'bound forms' comprise not

7 The affixes involved are all non-harmonizing ones, cf. $\mathbf{3 . 3}$ below. 
only affixes, affixoids and semiwords, but they reach well into the domain of 'words'. This classification is given in Table 1, where the dividing line in the middle is the subject of further discussion.

Table 1

A hierarchy of lexical items

\begin{tabular}{lccc}
\hline & \multicolumn{3}{c}{ TEST } \\
TyPe & Combinability & FCR & BCR \\
\hline word & + & + & + \\
semiword & - & + & + \\
\hline affixoid & - & - & + \\
affix & - & - & - \\
\hline
\end{tabular}

Following Aronoff's (1976; 1994) idea that gender and word class labels (such as 'noun', verb', etc.) are instructions to take up certain affixes but not others, or to occupy certain syntactic positions rather than others, we may argue that this classification of lexical items serves to identify them with respect to a particular set of operations they may undergo as against others they are insensitive to or with respect to particular syntactic positions they may occupy as contrasted with others that they cannot. Moreover, languages may vary according to (i) whether they allow CR in word formation, (ii) if they do, whether it works in both directions, and (iii) up to which level of lexical units CR extends. ${ }^{8}$

Italian, for instance, permits BCR of words, as in (32), but no FCR of either words or (suspected) semiwords, cf. (33).
(32) (a) pre-
o post-bellico
pre or post-war (adj.)
(b) pro-_ o anti-americano
pro or anti-American
(c) super-_ anzi extra-stanco
super even extra-tired

${ }^{8}$ It should be noted that $\mathrm{CR}$ seems to be confined to gapping contexts, i.e., the deletion site is surrounded by lexical material and structures in which deletion is at the edges, such as illustrated below, are disallowed.

(i) * _ shop or book-stand

(ii) *book-stand or newspaper _

But cf. also (37b) and (65) below. 
(33) (a) *mal-sane ed —-educate ill-healthy and (ill-)educated

$\begin{array}{cc}\text { (b) * post-bellico o } & \text {-revoluzionario } \\ \text { post-war or } & \text { revolution } \\ \text { (c) * pro-americano o } & \text {-italiano } \\ \text { pro-American or } & \text { Italian }\end{array}$

It may be the case that the classes of affixoids and semiwords are missing in Italian, since there is no coordination reduction in the following structures. Note that although the first prefix in (34a) is not syllabic, and therefore cannot be the locus of phonetic contrast, in (34b) both suffixes carry accent, thus in principle they could be contrasted.

(34) (a) $*_{\mathrm{s}-}$ o in-fortunato

un- or not-happy

(b) *virtu-ale e _-oso virtu-al and (virtu)-ous

Marathi has CR in both directions in compounds, cf. (35), but no CR below the level of autonomous words, cf. (36) ("prt" signals the obligatory compounding particle).

(35)
(a) aloo chi ani gobi chi bhaji potato prt and cauliflower prt curry 'potato (curry) and cauliflower curry'

(b) aloo chi bhaji ani potato prt curry and 'potato curry and (potato) bread'

(36) (a) saakhre-*(sarkha) ani mitha-sarkha sugar-like and salt-like 'sugar-(like) and salt-like'

(b) changul-*(pan) ani lahan-pan nice-ness and smallness 'niceness and smallness'

In languages that do not have right-headed compounds, as in Romanian or French, CR seems to be even more difficult. Yet, as Franck Floricic reports (personal communication), while there are no forms of (37a), cases of CR such as (37b-d) are perfectly possible.

Acta Linguistica Hungarica 54, 2007 
(37) (a) *les porte-avions et hélicoptères the-pl carry-airplanes and helicopters 'the aircraft and helicopter carriers'

(b) les pro-blocage et les anti the-pl for-freezing and the-pl against 'those for and those against freezing (prices, salaries, etc.)'

(c) les pro et les anti-blocage 'idem'

(d) les avec et les sans maillots the-pl with and the-pl without swimsuits 'those with and those without swimsuits'

The fact that the article occurs in both conjuncts shows that these are not instances of coordinating neoclassical items or prepositions. Note that CR involves only word-size items in these examples of exocentric compounds and only if they are final constituents, as illustrated in $(37 \mathrm{~b}-$ d) in contrast with (37a). CR works in both directions, and not only Latinate prefixes can induce $\mathrm{CR}$, as in $(37 \mathrm{~b}-\mathrm{c})$, but also prepositional constituents of compounds, as seen in (37d). ${ }^{9}$

\subsection{Justification for the difference between BCR and FCR}

The next question we address is why Backward Coordination Reduction is more permissive than Forward Coordination Reduction.

Wilder (1997) discusses backward deletion (BWD) and forward deletion (FWD) extensively. He proposes that BWD involves deletion of lexical forms in the phonological component, while (at least some) FWD sites arise through the base generation of formless elements that surface as gaps in the phonological component. BWD is phonologically governed, and (at least some) FWD phenomena are semantically oriented. The evidence comes from the observation that FWD imposes a constituency requirement, but BWD does not, and that there is no requirement of identity of agreement in FWD, which, according to Wilder, is due to the non-interpretability of Agr at the level of Logical Form. ${ }^{10}$

${ }^{9}$ An anonymous reviewer cautions that pro and anti can be independent words in spoken French. For more examples that may be relevant, cf. LesselingueVilloing (2002).

${ }^{10}$ Since agreement affixation on the predicate carries information marked on the subject in the cases concerned here, it provides no information for semantic interpretation, therefore it can be simply invisible at the level of Logical Form. 
In Wilder's original examples cited below, the string deleted by BWD in (38a) has no constituency. The comparable string erased by FWD in (38b) results in ungrammaticality, while the outcome of FWD in (38c) is acceptable, since it observes constituency. Finally, in (38d) the verb deleted carries plural agreement, although its counterpart in the first clause is singular.

(38) (a) John took [a crate [with [[TEN bWD Mary took [a crate [with [[TwENTY bottles] in it]]] outside

(b) *[John] [saw [three [BLUE cars]] arrive] and

FWD [John] [saw [three [RED cars]] depart]

(c) John [came at three] and Mary [ three], too

FWD

(d) John drinks wine and his kids drink cola.

FWD

In spite of Kiefer's (2000) claims that CR in compounds must observe constituency, deletion processes illustrated in (38a) can be found in compounds. In the following examples Backward Coordination Reduction, i.e., in Wilder's terminology, Backward Deletion, is illustrated in the two compounds in (39). As is seen from the bracketing, no constituency is observed in the strings deleted. In the examples here and below, semiwords are marked by italics.

(39) (a) [[gyors- író] nö] és [[gép -író] -nő $] \quad$ BCR fast writer woman and machine writer woman 'female stenographer and typist'

(b) [[bel- ügy] minisztériumølk] és [[kül- ügy] minisztériumok] internal (affairs ministries) and external affairs ministries 'ministries of internal and foreign affairs'

In (40), in turn, Forward Coordination Reduction, i.e., Forward Deletion, takes place, and the acceptable readings must comply with constituency requirements.

(40) (a) *[gyermek- [ideg -gondozók]] és [gyermek [ideg $\quad$-klinikák]] FCR child neurology centers and (child neurology) clinics

(b) *[kényszer- [gyógy- kezelések]] és [kényszer [gyógy eljárások]] forcible medical treatments and (forcible medical) procedures

That is, (40a) can mean 'pediatric neurology centers and pediatric clinics', but not 'pediatric neurology centers and pediatric neurology clinics' 
and (40b) can only mean 'forcible medical treatments and forcible procedures', and not 'forcible medical treatments and forcible medical procedures' as follows from the constraints reviewed above. The (a) examples in (39)-(40) have autonomous words in ellipsis, but the (b) examples contain semiwords, marked by italics, which shows that semiwords are on a par with the (autonomous or dependent) words in the (a) examples with respect to $\mathrm{BCR} / \mathrm{FCR}$ and constituent structure.

Let us now summarize our positions so far.

(41) (a) Backward Coordination Reduction requires simple phonological identity and exerts no constituency condition.

(b) Forward Coordination Reduction must be reconstructed from semantically relevant information, thus it must observe constituent structure.

(42) (a) Semiwords can undergo both BCR and FCR since they classify with words in this respect.

(b) Affixoids can undergo BCR because it is allowed by the requirement of phonological identity of deleted material.

(c) FCR requires semantic reconstruction, available to word-sized items (words and semiwords) and thus inaccessible to affixoids.

If we view grammar as a complex system in which the depository of lexical items, the Lexicon, feeds syntactic operations whose outcome is interpreted in the bifurcation giving ultimately phonetic and semantic interpretations, or in other words, form and meaning, in the two interfaces of Phonetic Form and Logical Form, then we can conclude (43).

(43) (a) BCR arises through deletion in Phonetic Form.

(b) FCR arises through ellipsis and reconstruction in Logical Form.

That FCR cannot extend to affixoids is probably due to the fact that the minimal semantic entity is the word (including the semiword), and since semantic reconstruction makes use of such entities, the minimum unit of ellipsis is also the word. And while affixes and affixoids do have specific semantic properties, they are essentially word-internal and invisible to operations involving and relying on semantic independence. In retrospect, this property justifies the bold horizontal dividing line in Table 1 above. ${ }^{11}$

That BCR is phonologically based is shown also by the following set of examples from Hungarian, a language with extensive vowel harmony in

${ }^{11}$ We note here that Yatabe (2001) presents problematic cases of BCR that involve semantically unrelated items. 
suffixation, as was mentioned above. The privative affixoid -talan/telen is applicable in BCR only if both bases are of identical vowel harmony types. (44a) has back harmony, (44b) has front harmony in both bases, respectively, so BCR is fine. But in $(44 \mathrm{c}, \mathrm{d})$ the first conjunct is a word with a vowel harmony type different from that of the second conjunct, which renders BCR unacceptable.

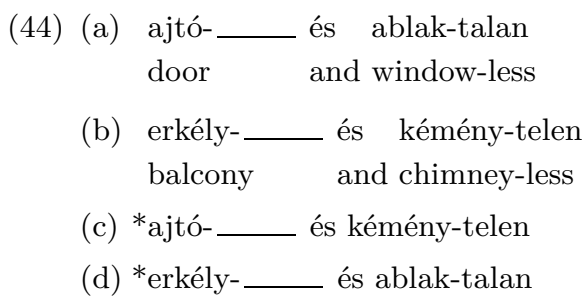

Note that in another vowel harmony language, Turkish, no similar requirement is enforced. Lewis $(1967,41)$, who was the first to describe the phenomenon and gave the name 'suspended affixation' to what has come to be called BCR, provides the examples cited in (45), where italics have been added in $(45 \mathrm{~b})$ to indicate the omitted affixes of a vowel harmony type differing from that of the ones retained in (45a). ${ }^{12}$

(45) (a) halk-ın acı ve sevinç-ler-i

people-gen sorrow and joy-pl-3sg

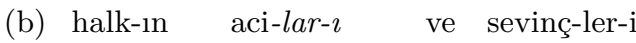

people-gen sorrow-pl-3sg and joy-pl-3sg

'the sorrows and joys of people'

It follows from this discussion that lexical items need to be characterized as to their status in the classification in Table 1. Although in the history of a language or even across groups of speakers their status may vary, it can always be determined by means of the operations outlined above, and we submit that such decisions form part of the native speakers' intuition concerning lexical items and their classes.

One example for a difference arising in the history of the language comes from Italian or French versus Spanish. As independently reported

${ }^{12}$ As was suggested to me by Ferenc Kiefer (personal communication), the contrast between Hungarian and Turkish may be due to the fact that Turkish vowel harmony is strictly phonologically defined, while Hungarian vowel harmony is at least partly lexically governed. 
by both Sergio Scalise and Franck Floricic (personal communication), -ment(e) counts as an affixoid in Spanish, but it is an affix in Italian and French, since it does not permit CR, cf.:

$\begin{array}{llll}\text { (46) } & \text { (a) dulce-___ y affectuosa-mente } & \text { Spanish } \\ \text { (b) } * \text { douce-___ et affectueuse-ment } & \text { French } \\ \text { (c) } * \text { dolce-___ e affettuosa-mente } & \text { Italian } \\ \text { sweet } & \text { and affectionate-ly } & \end{array}$

As to dialectal differences, the case of the Hungarian privative suffix cited above in (18) and (44) can serve as an example: CR of -talan/telen is not acceptable for a large class of speakers. The process of autonomous word $\rightarrow$ semiword $\rightarrow$ affixoid $\rightarrow$ affix is a natural development of grammaticalization and semantic bleaching, yet it is in principle possible, at any stage of the progression, to identify the class to which a given lexical item belongs.

\section{Further issues in coordination reduction in compounds}

\subsection{Words and nonwords in the two subtypes of coordination}

It is not only the directions of ellipsis that can be used to differentiate coordinate structures. They have subtypes according to the number of conjuncts they can take, as Dik (1968) argued. $n$-ary coordination (N-C) consists of a practically unlimited number of conjuncts, usually, but not necessarily, placing the conjunction only in front of the last conjunct in the list of items, as in (47). Canonical conjunctions in $(\mathrm{N}-\mathrm{C})$ are and, or, nor, and their ilk. The other subtype is binary coordination (B-C), in which only two conjuncts are possible, and consequently only one occurrence of the conjunction, which can come from the following non-definitive list: but, however, therefore, then, consequently, in turn, etc., as illustrated in (48).

(47) (a) [Ann, (and) Sue, and Mary] walked.

(b) Ann walked, (and) Sue talked, and Mary balked.

(48) (a) *[Ann, (*but) Sue, but Mary] talked.

(b) *Ann walked, (*but) Sue talked, but Mary balked.

(c) Ann walked, but Sue talked.

(d) Ann talked, therefore Sue walked. 
So far only constructions of $n$-ary coordination have been examined. In fact, Toman (1985) already made use of examples of binary coordination of autonomous words, without however noticing the difference between the two subtypes of coordination, cf.:

(49) weil das importierte Bier neben Ascorbinauch andere because the imported beer beside ascorbic also other schwefelige Säuren enthält sulphurous acids contains 'because imported beer contains besides ascorbic acid also other sulphurous acids'

Let us now examine how the various classes of lexical items behave with respect to binary coordination.

As was seen in (22) and (23), repeated below, both words and semiwords undergo both BCR and FCR in $n$-ary coordination. As before, semiwords are marked by italics. The (b) examples show neoclassical combining forms, while the semiwords in the (c) examples are of Germanic origin.

(50) (a) bookand newspaper-stands

BCR

(b) superand supra-national

(c) gossipor scandal-mongers

(51) (a) book-binders and -sellers

FCR

(b) anti-federalist and -nationalist (opinions)

(c) step-mothers or -fathers

In English no CR seems to be possible in binary coordination in either direction, cf.: ${ }^{13}$

(52) (a) *This is a booktherefore also a newspaper-stand.

BCR

(b) * She invited book-binders, though not -sellers.

FCR

As has been studied by Bánréti (1994), it is probably due to the differences in the syntactic parameter of ordering focused constituents preverbally that comparable constructions are fully acceptable in Hungarian, although in one direction only: backward coordination reduction is

${ }^{13}$ But note Wilder's (1997) example illustrating possible BCR in what can be classified as binary coordination: We must distinguish psycho from sociolinguistic claims. 
possible, but forward $\mathrm{CR}$ is not. (53) contains independent words in compounds. The example in (53c) shows the grammatical construction with the intended meaning of $(53 \mathrm{~b})$. The counterparts of constituents in ellipsis are bracketed below.

(53) (a) Anna tegnap könyv-__ ma azonban , meR Anna yesterday book today however újság-[árusokat hívott meg] newspaper-sellers invited prt

'Anna invited book-sellers yesterday, but newspaper-sellers today.'

(b) *Anna tegnap [könyv]-kötőket __, ma azonban __-árusokat Anna yesterday book-binders today however sellers [hívott meg] invited prt

(c) Anna tegnap könyv-kötőket, ma azonban könyv-árusokat hívott meg. 'Anna invited book-binders yesterday, but book-sellers today.'

As is illustrated by means of the two sites of ellipsis in (53b), what appeared to be forward CR, is in fact a complex case of forward CR and backward deletion, which may underlie the impossibility of the application of both in a single structure.

Semiwords can also take part in binary coordination reduction in Hungarian. In the examples below semiwords are again marked by italics. Both examples in (54) are cases of BCR; the difference between them lies in the positions of the semiwords. In (54a) they are initial and reduction is applied to the words in final positions, while in (54b) they are final and are themselves subjected to CR.

(54) (a) Anna előbb al-__ de aztán fö-orvos lett. Anna first sub but then head-physician became. 'Ann first became a resident, but then a head physician.'

(b) Anna igazgató-___ Erika azonban elnök-né_ akart lenni. Anna director Erika however president-wife wanted to-be 'Ann wanted to be a director's wife, but Erika wanted to be a president's wife.'

The examples in (55) show that forward coordination reduction is unavailable in binary coordination structures. 
(55) (a) Anna elöbb fö-orvos, aztán *(fö-)igazgató akart lenni Anna first head-physician then head-director wanted to-be 'Anna first wanted to be a head physician, and then a director-general.'

(b) Péter előbb telefon-szerü, de aztán *(telefon-) féle dolgokat gyüjtött. Peter first telephone-like but then telephone-kind things collected 'Peter first collected telephone-like things, but then things resembling telephones.'

If we move on to include the next level below semiwords, we will see that affixoids (marked by italics) cannot occur even in backward CR.

(56) (a) *Péter előbb ablak - aztán ajtó-talan házakat épített. Peter first window(less houses built) then door-less houses built 'Peter first built windowless houses, and then doorless ones.'

(b) *Anna feleség tént bánt a gyerekekel, de nem anya-ként bánt Anna wife (-as treated the children) but not mother-as treated a gyerekekkel. the children

'Ann treated the children as a wife, but not as a mother.'

To sum up: binary coordination tolerates only backward coordination reduction wherever $\mathrm{CR}$ is possible at all, and even where it is possible, it does not extend to the levels below semiwords. There are then two questions for us to answer: (a) why is forward CR impossible in binary coordination, and (b) why only words and semiwords can undergo CR in binary coordination?

Question (a) is not mysterious: CR processes must be unidirectional, i.e., either forward or backward deletion can take place between two conjoined clauses. Regarding question (b), we have seen that words and semiwords classify into a single category with respect to processes of ellipsis that involve semantic reconstruction. It appears then that although binary coordination allows only backward CR, it does not resemble the $\mathrm{BCR}$ processes in $n$-ary coordination. Because of the asymmetry of the two conjuncts, the ellipsis in binary coordination is presumably not a matter of phonological deletion; it must most probably have recourse to the semantic identification of the deleted material. Should that be the case, the requirement in force in FCR is invoked in binary coordination and no lexical item below the level of words and semiwords, i.e., below 
the bold line in Table 1, is accessible to the process. In short, binary coordination acknowledges only word-sized items in the operations of CR. ${ }^{14}$

\subsection{Backward and forward deletion in compounds and phrases}

One interesting side-effect of the difference between BWD and FWD can be observed in the behavior of compounds as compared to syntactic constructions. As is usually assumed, compounds are a result of a lexical operation that puts together two lexical items (whether words or semiwords) and yields another lexical item to be treated as a zero-level category, i.e., an unanalyzable minimal unit in syntax, or, as the case may be, as a lexical item used as input to another lexical process. Individual words combine into phrases in syntax, and their internal structure or constituents are accessible to syntactic processes, such as deletion.

Radford (1988, 203ff) noticed the distinction between strings like Cambridge student and Physics student, and provided the following tests and structures, respectively. ${ }^{15}$

(57) (a) Which student? The Cambridge one?

(b) $\left[{ }_{N^{\prime}}[\mathrm{NP}\right.$ Cambridge $]\left[\mathrm{N}^{\prime}\right.$ student $\left.]\right]$

(58) (a) Which student? *The physics one?

(b) $\left[_{\mathrm{N}^{\prime}}[\mathrm{NP}\right.$ Physics $][\mathrm{N}$ student $\left.]\right]$

Radford puts down the difference between (57) and (58) to the head word student being of the category $\mathrm{N}^{\prime}$ in (57), while an $\mathrm{N}$ in (58), which would account for the inapplicability of the "one test" in (58), since one substitutes for $\mathrm{N}^{\prime}$, rather than for $\mathrm{N}$. While this may be a correct account of the facts ${ }^{16}$ it is certainly the case that the "one test" is also inapplicable in compounds, cf.

${ }^{14}$ One anonymous reviewer inquires whether there are semiwords in Hungarian other than those illustrated in this paper. Although for reasons of simplicity of exposition I have made use of a limited variety of examples, there are c. 60 initial and 16 final semiwords attested to be productive in Hungarian. To list a few(a) initial: ál 'fake', déd 'great-grand', egyen 'uni(form)', leg 'most (superlative)', köz 'public', utó 'post'; (b) final: ellenes 'counter', felé 'to (x number of pieces)', mentes 'free'.

${ }^{15}$ I am grateful to Andrew Spencer for drawing my attention to this passage in Radford's book.

${ }^{16}$ Not everyone agrees, however. For example, Selkirk (1982), Lieber (1983), or Spencer (1991) consider expressions of the type of physics student as $\mathrm{N}+\mathrm{N}$ or 
(59) (a) *a window cleaner, and a door one

(b) *elevator repair and car one

(c) *mill wheels and car ones

And since one clearly identifies the word as its minimum domain of substitution, and the [head + complement] unit as its maximum domain of substitution, it cannot violate the integrity of lexical items as a syntactic substitute. Note that BWD, i.e., BCR works without any problems.

(60) (a) a window and a door cleaner

(b) elevator and car repair

(c) mill and car wheels

It is this difference that is at work in the disambiguation of compounds versus modifier + head phrases, such as illustrated below.

(61) (a) an English teacher and a French one (=teacher from France)

(b) *an English teacher and a French one (=teacher of French)

Observe also that similar backward reductions are less acceptable than in (60) in case of modifier + head constructions of the type of (57).

(62) (a) ?(I have met) Cambridge and London students

(b) ?the England and the Germany captains

The case is somewhat simpler in Hungarian, where deletion of the head noun in FWD does not include the case affix of the DP that it is a constituent of. In (63a) BWD is illustrated, which, as was seen above, does not respect constituent structure. In (63b) FWD takes place, and the head noun is omitted, but the case suffix is not.

(63) (a) Anna [a boldog ervest] Júlia pedig

Anna the happy (doctor-acc liked) Julia in-turn

[a szomorú orvos-t] szerette.

the sad doctor-acc liked

'Anna liked the happy doctor, and Julia liked the sad doctor.'

'root compounds'. Therefore, as an alternative to Radford's analysis, we may contend that (57) illustrates a modifier + head construction, whereas (58) a compound. 
(b) Anna a boldog orvost szerette, Júlia pedig [a szomorú $\emptyset-*(t)]$ ere 'Anna liked the happy doctor, and Julia the sad one.'

BWD is not to be reconstructed, thus case suffixes are dispensable, as in (64a). FWD is, however, different again, cf. (64b-c).

(64) (a) Anna a szem- ervos-t_szerete, Júlia pedig

Anna the eye- (doctor-acc liked) Julia in-turn

az ideg-orvos-t szerette.

the nerve-doctor-acc liked

'Anna liked the oculist, while Julia liked the neurologist.'

(b) *Anna a szem-orvos-t szerette, Júlia pedig

Anna the eye-doctor-acc liked Julia in-turn

az ideg- $\emptyset$-et

the nerve- $\emptyset$-acc liked

(c) Anna a szem-orvost szerette, Júlia pedig az ideg-orvos-t

'Anna liked the oculist, while Julia (liked) the neurologist.'

Backward deletion works the same way in both phrasal, i.e., syntactic, and lexical contexts, i.e., in compounds. But forward deletion differs in that while syntactic phrases can have their head noun (phrase)s in ellipsis, compounds cannot: in (64b) the head noun orvos 'doctor' cannot be omitted, unlike in the case of the head of a NP, as in (63b). Since the item in ellipsis is a word, we cannot rely on our generalizations above over the hierarchy of lexical items. Note, however, that the pattern realized in (64b) corresponds to the 'edge deletion' pattern excluded in fn. 8, that is, since the structure *[szem-orvos és ideg-_] 'eye-doctor and nerve(doctor)' is ungrammatical even in $n$-ary coordination, we have no reason to suppose that it will improve in the more restrictive context of binary coordination.

\subsection{Romance negative ellipsis}

Floricic (2006) reports an interesting construction available in some Romance languages, which, like the case of French "edge-deletion" illustrated in (37b) runs counter to the general pattern of CR as based on gapping contexts. They are apparently cases of forward CR, but differ from the examples presented so far in that the first conjunct is not com- 
posite and it is fully "reconstructed" in the second conjunct invariably introduced by the negative word.

(65) (a) cittadini [italiani e non___ ]

citizens Italian and non(-Italian)

Italian

(b) metodi [naturali e non _ $]$

methods natural and non(-natural)

(c) varios cientificos, [cristianos y no__], manifestaron Spanish various scientists Christian and non(-Christian) manifest

se escepticismo...

their scepticsm

As before, forward deletion is based on semantic units, i.e., words in the case under review. Why this type of construction is possible at all and why only the negative word can occur in the second conjunct are intriguing questions.

One way to approach the answer is to concentrate on the negative word. It may very well be the case that the postnominal adjectival modifiers are actually reduced relatives, containing the bare predicates. One related syntactic construction gives some support to this assumption. The negative word in several languages, including Spanish, can be used in elliptical predication structures, cf.

(66) Estas profesores son cristianos, los otros — no

these teachers are Christian-pl the-pl others not

'These teachers are Christian, the others are not.'

Consequently, ellipsis induced by the negative word is not a case of CR, but an instance of ellipsis in predicative constructions, seen even in the English sense translation above. The question now is not why FWD is possible in (65), but why it is not possible in a number of other Romance languages, in which postnominal modifiers are just as regular as in Spanish or Italian. One such language is French, in which this type of ellipsis cannot occur.

As Floricic (2006) remarks, the negative elliptical construction may well draw on properties of focus. Clearly, the second conjunct carries primary or pitch accent, and the two conjuncts are in semantic contrast, fulfilling the minimum requirement for focus prosody and interpretation. Since the discussion of focus in this context would lead us too far afield, we will not pursue this line here, but leave it to future research. 


\section{Conclusion}

In this paper we have shown that the territory between the word and the affix is not without sharp demarcation lines. Not only is there a clear distinction between autonomous and dependent words, but native speakers command demonstrable knowledge of the three further types of lexical items that must be listed in the inventories of forms of the languages that apply the processes reviewed here. Of the five classes three define word-like items: autonomous words, dependent words, and semiwords. All three undergo coordination reduction in both directions, and, crucially, forward coordination reduction, which operates only on semantic units. And since the minimal semantic unit is the word, a semiword must belong to the class of words. On the other side of the divide are lexical items below the level of words: affixoids, which have limited independence insofar as they undergo the phonologically based process of backward coordination reduction, and affixes, which have no independence at all since they are blind to any CR processes. The crucial distinction throughout has been shown to go back to the domains in which the processes of coordination reduction, and in general, deletion processes operate. In phonologically based deletion operations formal identity is called for, whereas in semantically based processes the minimal semantic unit cannot be broken up into its constituents.

\section{References}

Aronoff, Mark 1976. Word formation in generative grammar. MIT Press, Cambridge MA.

Aronoff, Mark 1994. Morphology by itself. Stems and inflectional classes. MIT Press, Cambridge MA.

Artstein, Ron 2002. Parts of words: Compositional semantics for prosodic constituents. Doctoral dissertation, Rutgers University, New Brunswick NJ.

(http://ruccs.rutgers.edu/ artstein/dissertation/arts11a4.pdf — accessed March 2006).

Bánréti, Zoltán 1994. Coordination. In: Ferenc Kiefer - Katalin É. Kiss (eds): The syntactic structure of Hungarian, 355-414. Academic Press, San Diego CA.

Bloomfield, Leonard 1933. Language. The University of Chicago Press, Chicago.

Booij, Geert E. 1985. Coordination reduction in complex words: A case for prosodic phonology. In: Harry van der Hulst - Norval Smith (eds): Advances in nonlinear phonology, 143-60. Foris, Dordrecht.

Booij, Geert E. 2005. Compounding and derivation: Evidence for Construction Morphology. In: Wolfgang U. Dressler-Dieter Kastovsky-Oskar E. Pfeiffer-Franz 
Rainer (eds): Morphology and its demarcations, 109-32. John Benjamins, Amsterdam \& Philadelphia.

Comrie, Bernard 1981. Language universals and linguistic typology. The University of Chicago Press, Chicago.

Di Sciullo, Anna Maria-Edwin Williams 1987. On the definition of word. MIT Press, Cambridge MA.

Dik, Simon 1968. Coordination. North-Holland, Amsterdam.

Fabb, Nigel 1998. Compounding. In: Spencer-Zwicky (1998, 66-84).

Floricic, Franck 2006. A propos de statut morpho-syntaxique de la négation connexionnelle en italien, en espagnol et en occitan languedocien. Ms. Université de Paris - Sorbonne Nouvelle.

Hacken, Pius ten 2000. Derivation and compounding. In: Geert Booij-Christian Lehmann - Joachim Mugdan (eds): Morphology: An international handbook on inflection and word-formation, 349-60. Walter de Gruyter, Berlin.

Halpern, Aaron L. 1998. Clitics. In: Spencer-Zwicky (1998, 101-22).

Höhle, Tilman N. 1982. Über Komposition und Derivation: Zur Konstituentenstruktur von Wortbildungsprodukten im Deutschen. In: Zeitschrift für Sprachwissenschaft $1: 76-112$.

Julien, Marit 2002. Syntactic heads and word formation. Oxford University Press, Oxford.

Kenesei, István-Robert M. Vago-Anna Fenyvesi 1998. Hungarian. Routledge, London \& New York.

Kiefer, Ferenc 2000. A szóösszetétel [Compounding]. In: Ferenc Kiefer (ed.): Strukturális magyar nyelvtan 3. Morfológia [A structural grammar of Hungarian, Vol. 3: Morphology], 519-67. Akadémiai Kiadó, Budapest.

Kiparsky, Paul 1975. Stress, syntax, and meter. In: Language 51:576-616.

Lesselingue, Chrystèle-Florence Villoing 2002. Aide-jardinier, aide-sage-femme, mots composés ou préfixés? Ms. Université Paris X-Nanterre, Université Paris VIIDenis Diderot.

(http://umr7023.free.fr/Downloads/LesselingueVilloing02aidejardinier.pdf — accessed January 2007).

Lewis, Geoffrey L. 1967. Turkish grammar. The Clarendon Press, Oxford.

Lieber, Rochelle 1983. Argument linking and compounding in English. In: Linguistic Inquiry $14: 251-86$.

Lyons, John 1968. Introduction to theoretical linguistics. Cambridge University Press, Cambridge.

Marchand, Hans 1969. The categories and types of present-day English wordformation: A synchronic-diachronic approach (Second edition). C. H. Beck, München.

McArthur, Tom (ed.) 1996. The Oxford companion to the English language. Oxford University Press, Oxford.

McManis, Carolyn - Monica Crabtree- Joyce Powers 1991. Language files. The Ohio State University Press, Columbus OH.

Acta Linguistica Hungarica 54, 2007 
Mohanan, Karuvannur Puthanveettil 1986. The theory of lexical phonology. Reidel, Dordrecht.

Nespor, Marina - Irene Vogel 1986. Prosodic phonology. Foris, Dordrecht.

Radford, Andrew 1988. Transformational grammar. Cambridge University Press, Cambridge.

Selkirk, Elizabeth O. 1982. The syntax of words (Linguistic Inquiry Monograph 7). MIT Press, Cambridge MA.

Siegel, Dorothy 1974/1979. Topics in English morphology. Garland Press, New York. (PhD dissertation, 1974).

Spencer, Andrew 1991. Morphological theory. Blackwell, Cambridge MA \& Oxford.

Spencer, Andrew - Arnold M. Zwicky (eds) 1998. The handbook of morphology. Blackwell, Oxford \& Malden MA.

Toman, Jindřich 1985. A discussion of coordination and word-syntax. In: Jindřich Toman (ed.): Studies in German grammar, 407-32. Foris, Dordrecht.

Vogel, Irene 1989. Prosodic constituents in Hungarian. In: Acta Linguistica Hungarica $39: 331-51$.

Wilder, Chris 1997. Some properties of ellipsis in coordination. In: Artemis AlexiadouT. Alan Hall (eds): Studies on universal grammar and typological variation, 59107. John Benjamins, Amsterdam \& Philadelphia.

Yatabe, Shuichi 2001. The syntax and semantics of left-node raising in Japanese. In: Dan Flickinger-Andreas Kathol (eds): Proceedings of the 7th international hpsg conference, 325-44. CSLI Publications, Stanford CA. 